\section{MP-101 膀胼癌細胞におけるCDDP耐性関連遗伝子 発現の検討}

\begin{abstract}
大阪大学 大学院 医学系研究科臓器制御外科学講座 (泌层器科) ${ }^{12}$

福井 辰成" 時実 孝至" 中山 雅志”佐藤 英一" 小野 豊” 扶上均”西村 和郎”野々村 祝夫" 奥山明彦

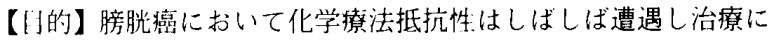
難涉することがあり予後不良因子の一つとなる。我々は膀胱癌細 胞株T24 cellを用いてCDDP耐性関連遺伝子発現を検討した。

【対象と方法】膀胱癌細胞株 T24 cell とCDDP 耐性 T24 cell (clone8-2)を用いmRNAレベルでの発現の差をDifferential display にて検討した。【結果】DDBJ Homology検索で多数の遺伝子が 候補として举げられた。今回そのうち3つの遺伝子につき報告す る。1）細胞の薬剤透過性に関連がある上思われるカリウムイオ ンチャンネルBK(Ca) channel beta4 subunit (KCNMB4 gene)。 2）caspase-9の活性化が報告されているWD repeat geneのファミ リーであるWDR3。3）細胞增殖能に影響するRNA polymerase $\mathrm{II}_{0}$ 以上の遺伝子についてCDDP投与前後での発現の変化を検討した。 膀胱癌 CDDP 薬郕耐性遗伝子
\end{abstract}

MP-102 Adriamycin-triggered intracellular signalling resulting in apoptosis in RT4 bladder carcinoma cells

\section{新潟大学医学部泌尿器科学教室}

ビリームウラジミル"笠原隆" 原鼠”川崎隆 高橋 公太"富田 善彦"

Adriamycin (ADM) treated RT4 cells underwent apoptosis, characterized by typical morphological features, including cell shrinkage and nuclear condensation. Apoptosis was also confirmed by the presence of internucleasomal DNA cleavage (TUNEL staining). Existence of apoptotic crosstalk between so called "extrinsic" and "intrinsic" pathways have been shown. Here we checked intracellular signal transduction in RT4 cells in response to ADM treatment. Expression of Fas, detected by FACScan, was slightly increased in RT4 after ADM treatment. ADM did not influence the Fas-ligand expression, as confirmed by Western blot. Moreover, Fas blocking antibody ZB4 did not affect the degree of ADM-triggered apoptosis. ADM resulted in decrease of mitochondrial membrane potential, cleavage of caspase 3, and increase of DEVD-specific activity in the course of apoptosis with the consequent cleavage of PARP.Thus, we can conclude, that ADM-triggered apoptosis in RT4 cells was executed exclusively via "intrinsic", mitochondrial pathway.

Transitional cell cancer Apoptosis Adriamycin

\title{
MP-103 腎孟尿管腫瘍の臨床的検討
}

\section{MP-104 近年の腎孟・尿管腫瘍臨床像の検討 一単一施設の過去10年間99例の検討からー}

\section{兵庫医科大学 泌尿器科}

前出 信之" 诨尾 圭介" 丸山豚雄" 善本 哲郎' 近藤宣幸" 野島 道生" 滝内 秀和”森 善則”島 博基"

【目的】当科で経験した腎盉尿管腫瘍症例について臨床的検討を 行った【対象と方法】1990年1月から2000年9月までに腎孟尿管 腫瘍の診断のもとに手術を施行した60例を対象とし, 方法は臨床 および病理組織所見と予後について検討した。【結果】発症年齢 は41歳から90歳 (平均69.8 111.0 ), 男性:50例, 女性10例で発生部 位は腎孟34例，尿管26例，右側30例，左側30例であった，膀胱腫 瘍の併発は27例 $(45 \%)$ で先行10例, 同時発生7例, 続発 10例. 臨床病期はStage I : 6例, Stage II $: 21$ 例, Stage III : 7例, Stage IV：17例．治㙩は腎孟尿管全摘術が47例，尿管部分切除術加6例 でこのうち1例は再発のため腎㙉泿管全摘術を施行した。病理組 織所見ではT.C.C.が57例（G1：11例，（i2：36例，G3：10例）， S.C.C.が3例で, 深達度はpTaが7例, pT1が22例, pT2が11例, pT3が16例，pT4が4例で $\mathrm{N}(+)$ は17例であった。予後は全体の 5年生存摔は68.7\%で，gradeが高くなるにしたがって悪くなる傾 问があったが有意差は珰めなかった。澡達度ではpT2以上の群は pT1以下の群と比較して生存率は有意に不良で, $\mathrm{N}(+)$ の群も $\mathrm{N}(-)$ の群上比較して有意に生存率が不良でまった。

腎血腫瘍 尿管腫瘍 臨床的検討

\section{東京慈恵会医科大学 医学部 泌尿器科'}

池本 庸"下村 達也"山田裕紀”湯本隆文”

長谷川太郎”阿部和弘" 大石幸彦”

【目的】近年腎孟・尿管腫瘍に対する一般的認識の高まりや，伥 路上皮腫瘍に対する有用な化学療法の開発導入に上り、本䏦煌の 臨床像や治療成績屯大きく变わってきている事か推察される。

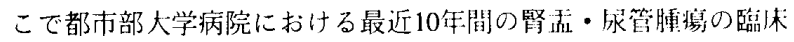
像の特徵を当院での経験から検証する、【対象及びう法】1990年 1月から1999年12月までの10年間に東京慈患会欧科大学付風病院

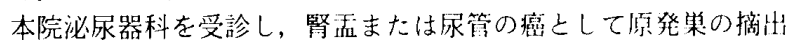
手術を施行し，病理診断の確定している99例を対象とした.99例 の平均年齢は64歳（中央值65歳）,男女比は5.2:1であった牛:存浮 の計算はKaplan-Meier法を,多変量解析はC $\operatorname{Cox} の$ 比例ハザード法 を用いた【結果扰よび考察】99例の全生:存㴏:は3年7 78\%,5年72\% であった健診やかかりつけ医で偶発的に発見された掟例は31例 に及び,これら偶発例の予後は非偶発例のそれ上り坟好の倾的で あった.分化度および病期に関しては明らかにこれらが商いはど 予後不良であった。術後再発に関しては䧛胱再発例の予後は他部 位再発例のそれより良好であり，膀脱阵発は予後不这老意味しな かった.多变量解析では予後不郎网子として分化度の重要性か小 唆されたが,症状の有無も予後因子として軽視できないものと考 えられた。

\section{腎孟 尿管 腫㾴}

